\title{
ATTITUDES TO POLYGAMY IN ENGLISH LAW
}

\author{
PRAKASH A SHAH*
}

\section{INTRODUCTION}

This article documents and discusses recent developments in English law ${ }^{1}$ towards polygamy. ${ }^{2}$ It begins by introducing the question of the legal treatment of polygamy in the Afro-Asian context ${ }^{3}$, and discussing the consequences that colonial and post-colonial developments may have had on the character (or visibility) of English case law on the subject. The article then turns to the examination of English developments in response to different phases of non-European immigration.

During the post-Second World War period the issue of polygamy initially became linked to the arrival and the different cultural patterns of Asian and African migrants who came to Britain. At this time, the courts reacted by trying to reconcile their historic disdain for the practice of polygamy with the demands of justice that the new migrants were making. In the early 1970s, however, the UK introduced statutory reform in a bid to force migrants to conform to British behavioural patterns, while disregarding the consequences for South Asians who potentially faced large scale de-recognition of their marital unions. Although judges reacted by mitigating the worst effects of the

* Lecturer, Department and School of Law, Queen Mary, University of London. The author is pleased to acknowledge the assistance of Nathalia Berkowitz, Senior Research Officer and Lawrence Jumbo, Library Officer, both at the Immigration Appellate Authority, for tracking down transcripts of unreported cases. The assistance of the staff of the Administrative Court office at the Supreme Court is also acknowledged. The author is extremely grateful for helpful comments about the drafting and content of this article to Dr Werner F Menski, Senior lecturer in South Asian laws at the School of Oriental and African Studies, London, to Dr Roger Ballard, Director of the Centre for Applied South Asian Studies and Senior Lecturer in the Department of Religions at the University of Manchester, to Hiren Bhana Mistry in Toronto, to Chenjerai Shire and Augustina Akoto, at the School of Oriental and African Studies, and to Navtej Singh Ahluwalia, Barrister. Errors remain the author's responsibility.

1 Although this article is based on a study of English law it has been necessary to retain references to 'Britain' or the 'UK' as the context demanded. Readers should note that slightly different situations prevail under English, Northern Irish, and Scots law, however. Where necessary, clarification is provided as to the situation in Scotland. It should be noted that the Scots legal position has largely been unclear given the paucity of case law on the subject, but it will be noted that it now approximates that prevailing in English law.

2 'Polygamy' denotes the practice of either women or men taking more than one spouseknown as 'polyandry' and 'polygyny' respectively. In this article polygamy is used to mean polygyny. This article does not attempt to address the issue of concubinage that is familiar to several Afro-Asian legal systems.

3 The term 'Afro-Asian' is used here to mean 'African and Asian', and is hence similar to the use of 'Anglo-American'. It is not meant in the sense of a hyphenated identity such as 'ScottishMuslim' or 'Italo-American'. 
legislation, the situation remained unsatisfactory, as the ability of South Asian men to enter into plural marriage could still be limited, or so it seemed, by the manipulation of the concept of domicile.

This became apparent especially when immigration officials took advantage of legal ambiguities by deciding to refuse South Asian women who sought entry under the family reunion provisions. From the late 1970s therefore, with the onset of family reunion among Pakistanis and later, Bangladeshis, a considerable case law developed that raised the problem of the validity of polygamous marriages, particularly when the admission of second wives was at issue. With the peaking of family reunion among Bangladeshi migrants, the legal system reacted again with the attempted ban on the admission of second wives under the Immigration Act of 1988.

It is argued here that English law has not achieved the aim of eliminating polygamy as ethnic minorities continue to navigate among various legal levels to circumvent official laws. Instead, the position taken at official level has been maintained and strengthened at the expense of women and against the best interests of their children. It is therefore further argued that the legal system needs to respond in a more sensitive manner to non-English marital practices as the current pattern of judicial disablement results in a lack of legal protection for the most vulnerable groups. As such, this case study of polygamy also provides a more general lesson of how a dominant legal system is ill-advised to attempt to impose a mono-cultural and ethnocentric regime upon a legally pluralist social base.

\section{THE COMPARATIVE LAW CONTEXT}

An important feature of Afro-Asian legal systems has been the continuing maintenance of systems of personal law since pre-modern times. These states tend to operate on the premise that, particularly in the realm of family law, the customary and religious law of the group concerned prevails, and generally governs the relations among members of that group. While state law has often intervened to regulate elements of these personal laws during the colonial and post-colonial periods, the latter still largely form the basis of the social and, therefore, legal order. ${ }^{4}$ In such systems a larger zone of self-regulation among variously constituted ethnic communities is allowed. This situation has been described as 'weak' legal pluralism. ${ }^{5}$ In this scenario, the state claims formal

\footnotetext{
${ }^{4}$ For a definition of 'personal law' see J Duncan M Derrett, Religion, Law and the State in India (Delhi: Oxford University Press, 1968), 39-41. See further, M Hooker, Legal Pluralism: An Introduction to Colonial and Neo-colonial Laws (Oxford: Oxford University Press, 1975). For the argument that personal law systems pre-date the colonial impact, see Werner Menski, Comparative Law in a Global Context. The Legal Systems of Asia and Africa (London: Platinium, 2000), 131-2.

5 John Griffiths, 'What is Legal Pluralism?' (1986) 24 Journal of Legal Pluralism and Unofficial Law 1-56.
} 
superiority through the 'official law', while allowing the maintenance of, and recognising the consequences produced by, subordinate legal orders. ${ }^{6}$ This approach is quite different to that prevailing in most Western unitary states which are characterised by state legal systems that generally claim an exclusive space for legal ordering, thus acknowledging minimal, if any, space for nonstate ordering systems. They also tend to emphasise uniformity as a desired goal of legal development. This goal, as we see below, is ill-suited to the plural nature of Afro-Asian societies, and has also caused problems in accommodating Afro-Asian legal cultures that have been reconstituting in Western societies. The above characteristics of Afro-Asian legal systems, fundamentally different from Western legal systems, have had a crucial bearing on the former's approach to the regulation of family systems that allow for polygamy.

In many Afro-Asian societies polygamy has been a long-standing practice that has often been recognised by the official legal sphere. Different states have adopted various approaches to its legal control, however, though few can be said to have achieved its outright abolition despite the modernisation euphoria that attended post-independence family law reforms. Among South Asian states, from which a large proportion of ethnic minorities in Britain originate, various approaches to legal regulation have been attempted. Modern Hindu law in India, which covers Buddhists, Sikhs, and Jains too, goes furthest in this respect and potentially criminalises it. Under the Hindu Marriage Act 1955 a second marriage may also be declared void. This has not prevented Indian courts from recognising the legal consequences of polygamy, however, as the full enforcement of the statute law is seen as often leading to injustice for the women and children concerned. In Pakistan and Bangladesh, Hindus continue to be regulated by Hindu personal law, which allows polygamy. The Indian Hindu legal provisions were also applied in similar form in Kenya and Uganda (though not in Tanzania) just prior to independence, with as yet unascertained consequences. On the other hand, the Muslim shari' $a$ is recognised in India, permitting Muslim men to marry up to four wives, although the absence of statutory regulation in this area has not meant the absence of any control on polygamy and its consequences by the courts. In Pakistan and Bangladesh observance of certain statutory conditions prior to contracting a second marriage are stipulated by the Muslim Family Laws Ordinance of 1961. Noncompliance with these conditions does not result in voiding of the marriage, however, and judges have still had to grapple with the difficult position of first or second wives who reluctantly find themselves in polygamous situations. ${ }^{7}$

6 The term 'official law' is used by Masaji Chiba (ed), Asian Indigenous Law in Interaction with Received Law. (KPI: London and New York, 1986), 56 to mean 'the legal system sanctioned by the legitimate authority of a country'.

7 See in detail Menski, Modern Indian Family Law (Richmond, Surrey: Curzon, 2001), 139-230 on India; Doreen Hinchcliffe, 'Polygamy in Traditional and Contemporary Islamic Law' (1970) 1(8) Islam and the Modern Age, 13-38 and David Pearl and Menski, Muslim Family Law, 3rd edn (London: Sweet \& Maxwell, 1998), 237-73 on Muslim law in South Asia and elsewhere; and J Duncan M Derrett, Introduction to Modern Hindu Law (London: Oxford University Press, 
In all these South Asian jurisdictions polygamy continues to be observed as a social practice among Hindus, Muslims, and others. It is notable, however, that no state law, and arguably no customary, personal or religious law recognises an untrammelled power of men to take as many wives as possible and that there are some norms regulating the practice at different levels. This is especially so when the first wife objects to a second marriage or is effectively deserted without being accorded the rights of a wife or the dues owed to her consequent to divorce, or when a second wife is duped into believing that no prior marital relationship exists. On the other hand, despite the views of many commentators that an outright ban is the right or obvious course for South Asian countries, this may not in fact be the right approach. Although such legislation has been passed as a means of modernising Hindu law in India, and in Turkey and Tunisia, it has not absolved official fora from finding appropriate solutions to the plight of women and children and results rather in the practice 'going underground'. ${ }^{8}$ The uncritical acceptance of the view that polygamy has been legislatively 'abolished' in its countries of origin may be part of the explanation as to why there are so few reported cases in Britain on such issues concerning Hindus, Sikhs or migrants from Turkey.

In the English case of Prakasho $v$ Sing ${ }^{9}$ the neglected wife's right of recourse to the court was resisted by the husband on the basis that their Sikh marriage celebrated in India had been entered into on the basis that it was potentially polygamous. In order to provide a remedy, however, the Divisional Court found it necessary to hold that the Hindu Marriage Act 1955, which had been enacted since the marriage took place, had converted the marriage into a monogamous one. While the judge's action is understandable, in that he clearly saw that the potential polygamy issue was being raised only to defeat

1963), 535-56 on Hindu law in East Africa. In Kenya the applicable law is found in the Hindu Marriage and Divorce Ordinance, 1960 and in Uganda in the Hindu Marriage and Divorce Ordinance, 1961. Nuala Mole, Immigration: Family Entry and Settlement (Bristol: Jordan and Sons, 1987), 44 observes that: 'The form of Hindu and Muslim marriage is broadly the same amongst the East African Asian communities as in the Indian subcontinent except that polygamy is rare amongst East African Asian Muslims and is not condoned by most communities.' For South Asian Muslims, see similarly Cynthia Salvadori, Through Open Doors. A View of Asian Cultures in Kenya, rev edn (Nairobi: Kenway Publications, 1989), 186 n and Hinchcliffe, op cit, 27-8 who notes the rarity of polygamy among Ismaili Khojas in Africa, and points to a Holy firman issued by the Aga Khan in 1962, contained within part 7 of the Constitution, that forbade the practice.

8 Menski, Modern Indian Family Law, 201-2 on Turkey and Tunisia and Ihsan Yilmaz, 'Dynamic Legal Pluralism and the Reconstruction of Unofficial Muslim laws in England, Turkey and Pakistan' (unpublished PhD thesis. London: School of Oriental and African Studies, 1999), 228-34 on Turkey. In the recent case of Hassen v Director of Public Prosecutions (CO/182/97), 30 July 1997, QBD (unreported) a conviction of a Tunisian defendant for 'bigamy' was quashed ultimately on the basis that the prosecution had not been based on firm evidence about the legal position in Tunisia, where the defendant had contracted a first marriage. He, however, appeared to maintain that under Tunisian law he was allowed to enter into plural marriage. While not conclusive, this background to the case at least raises the question of the disjunction between the official Tunisian law and personal law.

9 [1966] P 233, [1967] 1 All ER 737. 
the wife's claim, the case also ratifies the fiction that since the 1955 Act, Hindu, Sikh, Jain, or Buddhist marriages could only be monogamous. ${ }^{10}$ English law also criminalises polygamy under section 57 of the Offences Against the Person Act 1861. In $R v$ Sagoo $^{11}$ a Sikh man from Kenya who was married prior to the adoption of the Indian-inspired legislation there in 1960, then married another woman in England. His conviction for bigamy was upheld on the basis that while his first marriage had been potentially polygamous, this marriage had been converted to a monogamous marriage as a domicile of choice had been acquired in England. Marrying again in England therefore laid him open to a charge of bigamy. Both cases therefore illustrate different ways in which pressure can be applied to drive polygamy underground. ${ }^{12}$ On the other hand, the failure to perceive socio-legal realities among ethnic minorities may well reflect wishful thinking about English (and Scottish) law's claims of also having 'abolished' polygamy, along lines of what Menski has called 'legocentric hubris'. 13

These as well as some alternative explanations may have to be sought for the relative absence of recent case law relating to sub-Saharan Africans settling or settled in Britain. ${ }^{14}$ As in other areas of concern to Africans in Britain, research on polygamy lags behind that concerning other groups. Earlier research on African jurisdictions, particularly on the colonial period, indicates that polygamy was identified as one of the practices most obviously opposed by the missionary zeal displayed by Christian churches anxious to gain conversions to their tenets. ${ }^{15}$ While Muslim law was generally recognised, the colonial states were, at the same time, faced with having to make uneasy compromises between the churches' positions and the political imperative of minimising interference in ancestral African practices. ${ }^{16}$ The balance

10 See to similar effect, David Pearl, Family Law and the Immigrant Communities (Bristol: Jordan and Sons, 1986), 39 and Carolyn Hamilton, Family, Law and Religion (London: Sweet \&Maxwell, 1995), 66. For earlier Hindu cases in British courts see Archana Parashar, 'Polygamous Marriage in Conflict of Laws' (1982) II(3) Islamic and Comparative Law Quarterly $187-208$ at $192-3$.

11 [1975] QB 885.

12 Two earlier prosecutions against imams for not following English rules on solemnisation, $R$ $v$ Mohamed (Ali) [1964] 2 QB 350 (actually a case from 1943) and $R v$ Bham [1966] 1 QB 159, also involve polygamy in the background, and conclude by effectively de-recognising nikah ceremonies as a condition of avoiding criminal penalties. Another case with similar implications, $R v$ Rahman [1949] 2 All ER 165, is a bigamy conviction where the husband already had a first wife in India. This case was formally overruled in Bham. All three cases involved English women marrying South Asian men.

13 Menski, Comparative Law.

14 For earlier potential polygamy cases see Ohochuku v Ohochuku [1960] 1 All ER 253 concerning Nigerian Christians and Sowa v Sowa [1961] 1 All ER 687 concerning Ghanaians.

15 Arthur Phillips and Henry F Morris, Marriage Laws in Africa (London: Oxford University Press, for International African Institute, 1971); Morris, 'Indirect Rule and the Law of Marriage', HF Morris and James S Read (eds), Indirect Rule and the Search for Justice. Essays in East African Legal History (Oxford: Clarendon Press, 1972), 213-50.

16 JND Anderson, Islamic law in Africa (London: HMSO, 1954) is a useful source for Islamic law in British-dominated Africa. Phillips (in Phillips and Morris, Marriage Laws in Africa, 86) explains the 'softer' attitude adopted by the colonial states in Africa with respect to polygamy: 'It may be that the policies of the British and French governments have been to some extent influ- 
was inevitably found somewhere in the middle and colonial practice varied greatly from region to region, from denying Christian converts or those who had registered their marriages with the state the capacity to marry polygamously, to criminalizing the practice. However, the various statutory enactments by colonial states combined with missionary exhortations, whether strictly enforced or not, did have a destabilising effect on African practices such as polygamy. Phillips' observation that 'there has seldom been any dispute as to the inconsistency of polygamous customs with civilised standards of life . . ${ }^{17}$ is an academic reflection of the one-sidedness with which autochthonous perspectives were marginalised. While there has not been much emphasis on amending offensive legislative postures in the post-independence era, it does appear that the strictures that had previously been put into place have quietly been allowed to lapse. ${ }^{18}$ How this history affects present day African attitudes, particularly those of migrants navigating among various legal levels, obviously requires further exploration, although there is much anecdotal evidence that polygamous practices are simply not being communicated to British officialdom (and this seems so also for African Muslims, as well as Ethiopians who do not share a colonial history). This mutual stand-off is not going to be sustainable for long as sub-Saharan Africans are rapidly re-emerging as a significant component of the UK's ethnic minority population.

\section{CONTROL THROUGH CHOICE OF LAW RULES}

\section{A. English Private International Law and the Refusal to see Personal Law}

Since at least the late-nineteenth century English law has found the concept of polygamy difficult to deal with or even recognise for the purposes of disputes within its courts, which upheld a self-consciously Christian viewpoint, even in cases where parties had married under an overseas legal system that accorded recognition to polygamy. This reluctance to accord recognition or award relief in polygamy cases was in large measure due to the long shadow cast by the decision in Hyde v Hyde, in which Lord Penzance had declared that 'marriage, as understood in Christendom, may for this purpose be defined as the volun-

enced by their experience and commitments in other parts of the world (eg, India and North Africa) where Muslim law prevails.'

17 In Phillips and Morris, Marriage Laws in Africa, 86.

18 For confirmation of this view in light of social realities in Nigeria, see Emeka Iwuji, Marriage Form in Nigeria (Rome: Tipolitografia, 1983), and in Ghana, see Ken Y Yeboa, 'Bigamy and Islamic Marriages in the Law of Ghana: the Legislator's Dilemma or Studied Silence?' (1993-1995) XIX Review of Ghana Law, 69-83. On the other hand, in African countries where non-Orthodox Christianity has been accepted, a vigorous debate continues about the compatibility of Christian (Catholic) doctrine and traditional African customs including polygamy, particularly since Vatican II in the 1960s: see Peter M Kanyadago, Evangelizing Polygamous Families. Canonical and African Approaches (Eldoret, Kenya: AMECEA Gaba Publications, 1991). 
tary union for life of one man and one woman, to the exclusion of others'. 19 This generally inhospitable attitude in English law towards polygamy has been seen more recently as 'influenced by the rather condescending and intolerant attitude that was prevalent at that time towards Afro-Asian culture' ${ }^{20}$ As a result of the altered political status in the countries concerned, Britain was compelled to recognise the existence and the effectiveness of other states and their laws. However, the key factor in motivating change in the attitude of the courts, as Parashar points out, was the

ever-increasing number of immigrants from Asian and African countries. These people who had come from countries which had cultures entirely different from England brought their customs and traditions with them. They were validly married in their countries and could not be expected to go back to their countries for getting matrimonial relief. Hence the English judges found a way out by holding that [the] nature of marriage could change. The change in attitude was from a complete denial of validity to the position that a potentially polygamous marriage could actually become monogamous. ${ }^{21}$

Besides drawing attention to the link with the increased presence of Asian and African migrants, ${ }^{22}$ Parashar's key observation here is that, as a way of conferring recognition, these marriages had to first be converted by English law to monogamous ones before any application for relief could be entertained. This was an early portent of things that were to follow in that the reaction to increased migration was not to recognise 'alien' customs according to their own terms but rather to make them undergo a process of conversion first.

This assimilationist attitude also crucially informed the statutory reforms contained in the Matrimonial Proceedings (Polygamous Marriages) Act 1972 (later incorporated in the Matrimonial Causes Act 1973 (MCA)), even though this legislation signalled acceptance of the principle that parties to-potentially or actually_polygamous marriages could obtain relief under English matrimonial law. The Report of the Law Commission put forward one of the key considerations that informed the statutory reforms in the following way:

Finally, it is rightly argued that immigrants to England are not in a privileged position and are expected to conform to English standards of behaviour. However, it seems to us that parties to polygamous marriages are more likely to conform to English standards if English law imposes on them, so far as is practicable, the same family rights and obligations as are imposed on other married people. The denial of all relief cannot achieve any change in the standards of behaviour of people who have made their home in England. On the contrary,

19 (1886) LR 1, P\&D 130 at 133. For discussion see Sebastian Poulter, English Law and Ethnic Minority Customs (London: Butterworths), 47-51; Richard Jones and Gnanapala Welhengama, Ethnic Minorities in English Law (Group for Ethnic Minority Studies, School of Oriental and African Studies; Stoke on Trent: Trentham), 109-18.

20 Parashar, 'Polygamous Marriage', 206.

21 Ibid, 206-7

22 See similarly Lucy Carroll, 'Definition of a 'Potentially Polygamous' Marriage in English Law: a Dramatic Decision from the Court of Appeal (Hussain v Hussain)' (1984) IV(1-2) Islamic and Comparative Law Quarterly 61-71 at 63 and Hamilton, Family, 69. 
denial of relief not only permits parties to escape from their obligations, lawfully entered into under another legal system, but tends to perpetuate the polygamous situation because the marriage cannot be ended. ${ }^{23}$

The Law Commission was seeking, laudably it may be said, to provide relief in situations where parties were possibly likely to escape responsibilities incurred by entering into plural marriages. However, this was combined with the assimilationist starting point that English legal norms ought ultimately to prevail over any others, and with the underlying aim of assisting in the termination of polygamous unions.

The reforms also added hurdles in a move possibly designed to frustrate further judicial innovation. What became section 11(b) of the MCA 1973 provided that a party to a subsisting marriage cannot validly contract a second or subsequent marriage and that second or subsequent marriage would be void $a b$ initio. As far as the 'domestic' law was concerned plural marriages celebrated in England and Wales would not therefore be recognised while, as we have seen (at II above), it was already the case that attempting to enter into such a marriage could lead to criminal charges. Section 11(d) of the MCA 1973 then added to the list of grounds by which a marriage, celebrated overseas after 31 July 1971, could be treated as void:

(d) in the case of a polygamous marriage entered into outside England and Wales, that either party was at the time of the marriage domiciled in England and Wales.

This subsection, Poulter points out, was specifically presented as an apparent 'codification' of a pre-existing rule of private international law, despite (or possibly because of) some controversy as to the pre-existing position in common law, and despite the fact that the Law Commission's recommendations in their 1971 Report did not specifically advocate action in this area. ${ }^{24}$ Carroll records Professor Morris's recollection that the sub-section was introduced in response to Parliamentary opposition based on the erroneous supposition that the Bill legalised polygamous marriages. ${ }^{25}$ Very critically, Poulter suggests that the subsection was inserted without heed to the likely consequences for immigrant men and their wives:

the 'codification' of this supposed rule into statute law seems to have occurred without sufficient regard being paid to the likely consequences. This is because the provision did not merely prevent a white Englishman who is domiciled here from circumventing the ban on contracting polygamous marriages in this country by purporting to do so abroad. It was framed so widely that it appeared to apply equally to immigrants who had come to Britain from countries where capacity to marry is governed by a personal or religious law which permits polygamy. All the indications are that quite a large number of Muslim immigrants, for example,

${ }^{23}$ Law Commission, Family Law. Report on Polygamous Marriages (London: HMSO, 1972), 14.

${ }^{25}$ Carroll, 'Definition', 67.

24 Poulter, English Law, 55-6 
particularly from the Indian subcontinent, have not been marrying in England but have returned to their countries of origin and there entered into potentially polygamous marriages arranged by their families in accordance with the local and religious law. The return of men to find wives in the Indian subcontinent is partly explained by the comparative shortage of single Asian women living in this country. The apparent effect of the new statutory provision in the case of any such person who had acquired a domicile of choice in England was to render his or her marriage totally void. ${ }^{26}$

Clearly domicile was the key determinant here, as non-English domicilaries were considered as remaining free to conduct their affairs according to their personal or religious laws with the proviso that key facts such as marriage solemnisation took place outside the UK. Even here problems were being stored up as domicile and how it is acquired or lost was hardly an uncontentious issue, as we see later (III.C.).

The potential consequences of the developing social scenario, under an English conflicts law that was working itself into a corner, were brought to a head in the well-known case of Hussain v Hussain. ${ }^{27}$ This case concerned a matrimonial dispute and involved a couple who were in a de facto monogamous marriage. They had married in Pakistan in 1979, and the wife later applied to the court for a decree of judicial separation on grounds of the husband's 'unreasonable behaviour'. The husband relied on MCA section $11(\mathrm{~d})$ to deny that he was married at all, the marriage being potentially polygamous, an interpretation then in accord with the views of most commentators. ${ }^{28}$ The Court of Appeal, however, wisely disallowed him to rely on this specious reasoning, as he clearly appeared to have been married. The Court found that he could not possibly have been potentially polygamously married because, being an English domiciliary, his capacity to marry was governed by English law which only allowed monogamous marriages. He was therefore validly, though monogamously, married. The Court was also mindful of Britain's 'increasingly plural society' and, had its decision gone the other way, Poulter observes that it would have had 'widespread and profound repercussions on the Muslim community here'. ${ }^{29}$ Yet, the reasoning adopted by the Court of Appeal caused several academics and the Law Commission to comment on its potentially adverse or unclear implications.

Notably, the complaints focused on the fact that the decision applied only to marriages solemnised after 31 July 1971 and did not clarify the status of those solemnised earlier; ${ }^{30}$ the status of persons who conducted their affairs prior to the Hussain decision in the belief that under the MCA 1973 their marriages were void remained unclear; ${ }^{31}$ and where the woman was an English domiciliary, marriages celebrated in a jurisdiction allowing polygamy would still be considered potentially polygamous and therefore invalid under

\footnotetext{
26 Poulter, English Law, 56.

27 [1982] 1 All ER 369, (1983) 4 FLR 339

28 Carroll, 'Definition', 66-7, Poulter, English Law, 56.

29 Ibid, 58

30 Pearl, Family Law, 46.

31 Ibid, 47.
} 
section 11(d). ${ }^{32}$ The Law Commission has since advocated recognising actually monogamous marriages of English domiciled women married abroad under laws allowing polygamy, thus removing what now seems like obvious discrimination, although their legal position has been weak since the reforms of the early 1970s, if not earlier. ${ }^{33}$ Meanwhile, the validity under English law of the marriage of any such woman remained potentially subject to being questioned, and could have had immigration-related consequences which have already been seen under the hated primary purpose rule and which are thus not difficult to imagine occurring in practice. In that parallel scenario, characterised as a manifestation of heavy-handed 'state masculinism', judges acceded to the idea that Asian women in Britain effectively could not choose to marry a partner abroad. ${ }^{34}$ Reported immigration cases raising validity issues on the basis of potential polygamy do not seem to have emerged, however, and it seems that parties were normally informed about the invalidity of their marriage under English law but yet were granted entry clearance as discussed further below (III.B.).

Poulter pointed out that the underlying problem requiring a more radical solution here was the way in which the concept of domicile operated. He noted that the Law Commission, in its post-Hussain Working Paper of 1982, did consider the option of allowing Muslim husbands to marry a second wife in Bangladesh or Pakistan, for example, and giving full recognition to such marriages even where the man was considered an English domiciliary. ${ }^{35}$ This option was, however, rejected pending a general rethink about the law of domicile, and it was not revisited in its 1985 Report. ${ }^{36}$ Instead, the recommendations limited themselves to advocating recognition of actually monogamous marriages of English domiciled women married abroad under laws allowing polygamy. It seems that Poulter was rather generous in his interpretation of the Law Commission's Working Paper which specifically ruled out recognition of actually polygamous marriages on the grounds that it would not meet with 'general approval' and because of the difference in treatment among

32 Carroll, 'Definition', 68-71, Poulter, English Law, 58, Pearl, Family Law, 47.

33 Law Commission, Private International Law: Polygamous Marriages-Capacity to Contract a Polygamous Marriage and Related Issues. Law Commission Report, No 146, Scottish Law Commission Report No 96 (London: HMSO, 1985).

34 See, eg, Sumeina Masood [1992] Imm AR 69. For comment, see Sanjiv Sachdeva, The Primary Purpose Rule in British Immigration Law (Group for Ethnic Minority Studies, School of Oriental and African Studies; Stoke on Trent: Trentham, 1993), 155-8; Menski, 'South Asian Women in Britain, Family Integrity and the Primary Purpose Rule', Rohit Barot, Harriet Bradley and Steve Fenton (eds), Ethnicity, Gender and Social Change (Basingstoke: Macmillan and New York: St Martin's Press, 1999), 81-98.

35 Poulter, English Law, 60-1; Law Commission, Polygamous Marriages. Capacity to Contract a Polygamous Marriage and the Concept of a Potentially Polygamous Marriage. Law Commission Working Paper No. 83 and the Scottish Law Commission Consultative Memorandum No 56 (London: HMSO, 1982).

${ }^{36}$ Law Commission, Private International Law: Polygamous Marriages-Capacity to Contract a Polygamous Marriage and Related Issues (Law Commission Report, No 146, Scottish Law Commission Report, No. 96 London: HMSO, 1985). 
English domiciliaries to which this would lead. ${ }^{37}$ Any settlement, if it were to follow the Law Commission's thinking, would reinforce the message that English law would not countenance actually polygamous marriages for English domiciliaries, still thereby treating many ethnic minority men and women, once deemed to have acquired domicile in England, as if their personal laws were subject to absolute control by English law. (A similar position presumably prevailed in Scotland despite the absence of an equivalent to section 11(d) MCA.) ${ }^{38}$ The recommendations of the Law Commission have now been incorporated into statute by section 5 of the Private International Law (Miscellaneous Provisions) Act 1995 (see section 7 for Scotland), which limits itself to holding valid de facto monogamous marriages celebrated in jurisdictions allowing polygamy. While clearly attempting to solve the problem of the potential non-recognition of a huge number of marriages contracted abroad, this legislation also ends up preserving the fiction that English domiciled men and women cannot but enter into monogamous marriages. This mirrors the assimilationist position of English 'domestic' law that is justified on human rights and discrimination grounds. 39

The key issue here, which is symptomatic of a wider problem for English law (and, it seems, European private international law more generally), ${ }^{40}$ is that there is a continuing failure to distinguish between personal law and the relevant jurisdictional law. ${ }^{41}$ When English domicile is established therefore a person is simply not regarded as capable of contracting into an actually polygamous marriage. The underlying message is that English law seeks to control a person's personal law absolutely in such situations. Given then that the concept of domicile has been seen as the dominant determinant of capacity and that this concept itself is unwieldy and uncertain, this leaves room for all

37 Law Commission, Polygamous Marriages, 84.

38 Ibid, 107.

39 Sebastian Poulter, 'The Claim to a Separate Islamic system of Personal Law for British Muslims', Chibli Mallat and Jane Connors (eds), Islamic Family Law (London: Graham and Trotman, 1990), 147-66.

40 Marie-Claire Foblets, 'Conflicts of Law in Cross-Cultural Family Disputes in Europe Today. Who Will Reorient Conflicts Law?', Marie-Claire Foblets and Fons Strijbosch (eds), Relations Familiales Interculturelles/Cross Cultural Family Relations (Oñati: International Institute for the Sociology of Law, 1999, 27-45; Silvio Ferrari, 'Introduction', Silvio Ferrari and Anthony Bradney (eds), Islam and European Legal Systems (Aldershot: Ashgate, 2000), 1-9 esp. at 6-8.

41 Establishing just what is the 'personal law' here may not be a simple exercise. In the context of debates on shari'a not only are there differences as between the schools of law, but also with respect to the place of pre-Islamic customs, and serious consideration may have to be given to the latter and to how they are changing with migration. Salvadori, Through Open Doors, 184-7 explains this for South Asian Muslims in Kenya, and Roger Ballard, 'Popular Islam in Northern Pakistan and its Reconstruction in Britain' (Paper presented at the International Workshop on Islamic Mysticism in the West, Buxton, Derbyshire, 22-24 July 2001, also at: <http://www.casas.org.uk>) for South Asian Muslims in Pakistan and Britain. On Muslim law and customs, see Pearl and Menski, Muslim Family Law, 38-43, and for concerns focused on Britain, see Samia Bano, 'Muslim South Asian Women and Customary Law in Britain' 4 Journal of South Pacific Law. 
sorts of assimilationist assumptions or exclusionary agendas to be played out by discretionary manoeuvres in actual cases. Marginalizing the essentially hybrid legal reality of migrants in such situations will frequently have an immigration bearing. ${ }^{42}$ Even in the Hussain type scenario, given the couple's actually monogamous marriage, the attribution of English domicile to a Muslim man could still be read as a means of controlling his future freedom of action by barring him from contracting further valid marriages abroad altogether, thus obviating in advance the prospect of future settlement applications by a second wife and her children. The prospect of an English domiciled woman proposing to sponsor a husband who also happens to have a second wife with a potential claim to entry would presumably be totally unimaginable!

\section{B. Trends in Family Reunion and the Immigration Control Process}

By the mid-1980s immigration cases could be counted as one of the areas of litigation where questions relating to polygamous marriages were featuring prominently, matrimonial and social security cases representing the other key areas. ${ }^{43}$ The gradual build up of reported and unreported cases in this area can be linked to the changing migration pattern, particularly among South Asian groups in Britain, on the one hand, and the tighter controls that were being applied against their migration to the UK, on the other. Whereas in earlier decades the immigration of men referred to by Poulter (III.A. above) dominated the scene, the 1970s onwards saw the consolidation of families in Britain. It appears that even among the South Asian groups the patterns have varied and, to a certain extent, generalisations can be made about this. Ballard, writing about the Pakistani experience, states that during the 1970s there was a marked shift towards comprehensive family reunion. He continues:

While their British citizenship meant that male settlers' rights to reunite families could not be gainsaid, all sorts of administrative obstacles which hindered their ability to exercise those rights began to be introduced, and by the late 1970s lengthy

42 One line of cases concerns the imputation of polygamy where a prior divorce has not been recognised for failure to comply with the expectations of the official law. Rukshana Begum Choudhury (9665), 20 Jan 1993 (unreported) concerned a refusal to recognise a divorce given to a wife in Bangladesh on the basis that the husband had acquired a domicile in England by that time, and for that reason his subsequent marriage was also not recognised. The Immigration Appeal Tribunal reversed this finding, however, and held that he had never lost his domicile in Bangladesh. In Mohammed A. Hamid (14314), 10 Dec 1996 (unreported) the Immigration Appeal Tribunal heard the appeal of a wife initially refused leave to enter on the basis that her marriage to her Yemeni husband was polygamous. The Tribunal held, however, that neither the husband's prior talaq to his long-standing first wife, pronounced before an imam in Liverpool, nor the subsequent marriage at the Liverpool Islamic Cultural Centre, an unregistered building, were legally effective. See further, Pearl and Menski, Muslim Family Law, 382-98 on the problem of recognition of Muslim divorces in Britain; and Jones and Welhengama, Ethnic Minorities, 118-32 and Abla Mayss, 'Recognition of Foreign Divorces: Unwarrantable Ethnocentrism', John Murphy (ed), Ethnic Minorities, Their Families and the Law (Oxford, UK and Portland, Oregon: Hart, 2000), 51-70 on ethnic minority divorces more generally.

43 Pearl, Family Law, 40. 
queues had developed at each of the many stages in the process of gaining leave to enter. Yet although this was an effective way of reducing headline figures in the short term, it did not prevent the eventual arrival of persistent applicants, especially when they took their cases to the courts. Thus while the process of family reunion took much longer to complete among the Pakistanis than it had among the Indians . . . by 1991 the overwhelming majority of families had been reunited. ${ }^{44}$

Ballard here, apart from identifying the problems encountered in seeking to reunite families among Pakistanis, draws attention to the fact that this process was delayed as compared with groups from India. ${ }^{45}$

Still slower to take off and to peak was the process among Bangladeshis, as Ballard mentions elsewhere. ${ }^{46}$ Gardner and Shukur show that in the earlier period Bangladeshi migrant men were 'international commuters' who divided their time between working in the UK and their families in Bangladesh. ${ }^{47}$ However,

By the early 1970s this pattern began to change. New legislation had made movement back and forth between the two countries increasingly difficult, and many migrants had begun to fear that unless they claimed British nationality and brought their dependents to join them, their rights of free movement might evaporate altogether. The whole character of migration swiftly altered: new arrivals were now most likely to be the wives and children of earlier settlers entering officially as dependents.

This movement then appears to have peaked in the $1980 \mathrm{~s},{ }^{48}$ although it continued well into the $1990 \mathrm{~s}^{49}$ It also appears therefore that there was a mutually reinforcing effect between the perception of tighter immigration regulations and the desire to reunite the family rapidly in order avoid stricter controls. This would not however rule out the influence of other factors, particularly, the perception that a home abroad or 'desh pardesh', as captured by Ballard, could be safely established in externally alien conditions. ${ }^{50}$

44 Roger Ballard, 'The Pakistanis: Stability and Introspection', Ceri Peach (ed), Ethnicity in the 1991 Census. Volume Two. The Ethnic Minority Populations of Great Britain (London: HMSO, 1996), 121-49, at 126.

45 See also Ballard, 'Migration and Kinship: the Differential Effect of Marriage Rules on the Processes of Punjabi Migration to Britain', Colin Clarke, Ceri Peach, and Steven Vertovec (eds), South Asians Overseas. Migration and Ethnicity (Cambridge: Cambridge University Press, 1990), 219-49.

46 Roger Ballard, 'Introduction: the Emergence of Desh Pardesh', Ballard (ed), Desh Pardesh. The South Asian Presence in Britain (London: Hurst \& Co, 1994), 1-34 at 20. See also Satvinder S Juss, Discretion and Deviation in the Administration of Immigration Control (London: Sweet \& Maxwell, 1997), 47-8 to similar effect.

47 Katy Gardner and Abdus Shukur, "'I'm Bengali, I'm Asian, and I'm living here”. The Changing Identity of British Bengalis', Ballard (ed), Desh Pardesh, 142-64, at 150.

48 John Eade, Tim Vamplew, and Ceri Peach, 'The Bangladeshis: the Encapsulated Community', Peach (ed), Ethnicity in the 1991 Census. Volume Two. The Ethnic Minority Populations of Great Britain (London: HMSO, 1996), 150-60, at 151.

49 Ballard, 'Introduction', 20.

50 Ballard, Desh Pardesh. For Bangladeshis specifically see, Katy Gardner, Global Migrants, Local Lives. Travel and Transformation in Rural Bangladesh (Oxford: Clarendon Press, 1995), 114-21. 
When we turn to the process of immigration control we find that marriage relationships have often been doubted in South Asian family reunion cases for various reasons ${ }^{51}$, but the validity of marriages on the basis of polygamy only seems to be raised in Pakistani and Bangladeshi Muslim cases. One can only speculate at this stage as to the comparative absence of polygamy cases involving applicants from other Afro-Asian regions or traditions, although it may well be that the comparatively delayed family reunification processes among Pakistanis and Bangladeshis and the immigration controls consequently applied to this movement may provide one explanation. However, we cannot at this stage rule out the role of perceptions about official laws in the countries of origin (see II above) in determining South Asian Muslims as more obvious targets of control.

It was known that entry clearance officers (ECOs) were expected to conduct routine inquiries about the validity of marriages when dealing with spouse applications. To illustrate the type of consideration involved in such an inquiry Pearl uses the example of a Bangladeshi man who returns to Bangladesh and marries a second wife there, who subsequently gives birth to a son there and then applies for entry clearance to come to the UK. ${ }^{52} \mathrm{~A}$ threestage test needed to be performed in this illustration:

(1) What is the appropriate 'choice of law' rule which is used to determine the validity of the marriage? In other words, should the officer apply English law, or should he apply the Bangladesh law? Is there an English-law rule which enables him to make this choice of legal system?

(2) The traditional 'choice of law' rule is that the capacity to contract a marriage which is actually or potentially polygamous depends on the antenuptual domicile of both parties. If this rule is applied, and, as we shall see there are some authorities which suggest that other tests should apply, then two further questions are raised. First, what test is used to determine the parties' domiciles at the time of the marriage? Secondly, assuming it is held that the man is domiciled in England, what is the English law on capacity to contract actually or potentially polygamous marriages?

(3) Even if the [second] marriage ... is void in English law, does the child have a right of abode as the legitimate son of his father, independent of his mother's claim?

The rules leave considerable discretion in the hands of ECOs who were certainly not obliged to automatically accept the validity of either potentially or actually polygamous marriages. Although the test outlined by Pearl appears complicated, it does not seem that ECOs found it impossible to apply to find that second wives did not qualify for entry clearance on the basis that the second marriage was void under English conflicts law. In order that ECOs could ascertain how the marriage in question ought to be treated, a domicile

51 Sachdeva, The Primary Purpose Rule, 108-11; Juss, Discretion.

52 Pearl, Family Law, 40-1. 
questionnaire appears to have been in use at least since the mid-1970s. The Commission for Racial Equality pointed out, in evidence to the Law Commission, that domicile, 'an abstract concept of legal art', was not generally understood and that individuals were not aware that the domicile questionnaire was used for the purpose of ascertaining the husband's domicile at the time of the marriage. It found this objectionable because the document neither explained its purpose not indicated that it might be desirable for the person required to complete it to obtain advice prior to doing so. ${ }^{53}$

In practice, wives of men who were considered as domiciled in Britain were admitted if the marriage was actually monogamous. However, parties to actually monogamous unions were still warned by ECOs that, if in polygamous form where the husband's domicile was in doubt, their marriages may not be recognised in the UK. ${ }^{54}$ As the CRE pointed out in its evidence to the Law Commission, there was inevitably an adverse effect on parties when they were told by Home Office officials that their marriage was void and that, for their protection, they should go through a further ceremony of marriage in the UK. ${ }^{55}$ Here again we can see indirect pressures to convert potentially polygamous marriages to monogamous form. On the other hand, by allowing entry in practice, ECOs and the Home Office avoided openly raising the issue of the potential invalidity of such marriages, and we have seen that this only came to a head in Hussain when a recalcitrant husband sought to obtain an advantage by claiming that under English law his marriage had never been valid.

As for the status of children, as raised by Pearl in his third question (above), the Legitimacy Act of 1976 provided that a child of a marriage considered void would still be deemed legitimate if at the time of intercourse resulting in birth, both or either of the parties reasonably believed that the marriage was valid. ${ }^{56}$ It appears therefore that refusals were generally made in cases where a wife was party to an actually polygamous marriage and it was concluded that the husband had acquired an English domicile prior to the marriage at issue, even though the children of the marriage may well be considered legitimate and therefore entitled to citizenship or entry clearance. As we shall see (IV below) the status of such children seeking entry was also to be downgraded in time.

\section{The Emergence of Immigration-related Cases and the Private International Law Response}

The key reported case that reached the Immigration Appeal Tribunal in the early phase of development from the mid-1970s is Zahra and Another $v$ Visa

\footnotetext{
53 Law Commission, Polygamous Marriages, 47-8. For more recent developments see Ian A Macdonald and Frances Webber (eds), Immigration Law and Practice in the United Kingdom (London: Butterworths, 2001), 423-4.

54 Law Commission, Polygamous Marriages, 52.

55 Ibid, 47-8

56 Pearl, Family Law, 48.
} 
Officer, Islamabad. ${ }^{57}$ Tasleem Zahra and Yasar Arafat, citizens of Pakistan, both applied in November 1975 to the visa officer in the British Embassy in Islamabad for entry clearance to join Mr Talib Hussain Shah for settlement in the UK as his second wife and their son. ${ }^{58}$ The marriage had taken place in October 1974. The visa officer was satisfied that the applicant was the sponsor's second wife. However, because he already had a first wife at the time of the marriage and because the view had been formed that the sponsor was domiciled in England at the time, although the marriage might be valid by Pakistani law, under English law the sponsor had no capacity to contract an actually polygamous marriage. The marriage was thus declared void. On appeal, the adjudicator and the Immigration Appeal Tribunal upheld this approach. The Immigration Appeal Tribunal leaned in favour of the sponsor's response to the domicile questionnaire that he found the climate in Pakistan 'too bad' and therefore wished to retire in the UK. Applying section 11(d) of the MCA 1973, it was agreed that the marriage was void. Therefore UK immigration law had quite early on adopted the so-called 'traditional' or 'dual domicile' (or 'prenuptial' or 'ante-nuptial') test to exclude second wives by simply refusing to recognise the validity of their marriages. Pearl informs us that this meant specifically excluding from the picture the legal view taken in the foreign legal system-in this case Pakistan-regarding validity of marriage even though that consideration had specifically been included as a sort of saving provision in section 14(1) of the MCA 1973. ${ }^{59}$ A similar approach was apparently followed in other immigration cases that reached the Immigration Appeal Tribunal-Pearl mentions two such cases of applicants from Bangladesh. ${ }^{60}$

At this time the Immigration Rules carried a provision stating that a 'woman who has been living in permanent association with a man ... may be admitted as if she were his wife, due account being taken of any local custom or tradition tending to establish the permanence of the association' ${ }^{61}$ It was also therefore argued before the IAT in Zahra that the applicant ought to be allowed entry clearance under this provision. The IAT, however, followed its own ruling in a case involving a Bangladeshi applicant Johanara Begum ${ }^{62}$ that had raised essentially the same point, and held that the Rule in question:

is intended to deal with, so to speak, a monogamous situation. If it were to be otherwise an oriental pasha with a harem of several wives might be entitled to bring them all to this country, even if he were domiciled here, provided that he otherwise satisfied the requirements of this paragraph. This is clearly absurd.

\footnotetext{
57 [1979-80] Imm AR 48; Pearl, Family Law, 42-3.

58 In this case, it appears that the son could not benefit from the Legitimacy Act 1976 as the application pre-dated the statute.

59 Pearl, Family Law, 43.

60 Johanara Begum and Others v ECO, Dacca (1261), 9 June 1978, and Arifun Nessa and Others v ECO, Dacca (3392), 1984 (both unreported); Pearl, Family Law, 43.

$61 \mathrm{HC} 81$ (1973), para 37, equivalent paragraphs also to be found in other Rules in force at the time. 
That case, we are informed ${ }^{63}$, was also followed by the Tribunal again in Visa Officer, Islamabad v Zaitoon Begum. ${ }^{64}$ After restating the above-mentioned paragraph the new Immigration Rules of 1980 carried a general proviso that:

A woman is not, however, to be admitted under this provision unless any previous marriage by either party has permanently broken down. Nor may she be admitted if the man has already been joined by his wife, or another woman admitted under this paragraph, whether or not the relationship subsists.

This new paragraph was obviously inserted as a means of 'codifying' the effect of the decided cases, thus reducing room for judicial discretion in future, but it also indicated that the immigration judiciary here were influencing the gradual hardening of attitudes by invoking imagined oriental pashas!

The Zahra decision may have been a turning point in that while in later cases, the Tribunal's approach to retention or loss of domicile seems to have kept shifting somewhat, it remained the benchmark as far as the choice of law rules were concerned. ${ }^{65}$ In other words, here was a decision giving priority to English conflicts of law and thus establishing the essential parameters of legal relevance, and perhaps it is not surprising that ECOs were now concentrating on domicile as a means of denying the validity of marriages, and thus denying entry. Corroborating this, Fransman recalls that 'the respondent in many immigration appeals has sought to argue that the domicile of origin has been abandoned in favour of a domicile of choice'. ${ }^{6}$

The strait-jacketing effect of the dominant conflicts discourse meant that there were occasionally very awkward moments for the Tribunal which saw the injustice behind some decisions refusing entry. In one case-Fazalan Bibi and Others $v$ VO, Islamabad ${ }^{67}$ - the Tribunal took into account, as one of several factors indicating the sponsor's retention of the domicile of origin, the fact that: 'The sponsor is a Muslim and undoubtedly there are aspects of Western culture which he would find repugnant.'! A right result for the wrong reasons? Perhaps, but it may be noted that the Tribunal appeared also fairly impressed with the fact that the sponsor's first wife remained in Pakistan. Pearl and Fransman, however, cite several other determinations in which the Tribunal appears to adopt a more balanced approach and leans more often in favour of retention of the domicile of origin, thereby also facilitating the recognition of the validity of second marriages. ${ }^{68}$

With Professor Jackson's appointment as Vice-President of the Tribunal we find, among the reported decisions, two in which a definite change of

63 At [1979-80] Imm AR 51.

64 (1642), 5 Nov 1979 (unreported).

65 Pearl, Family Law, 43, 45.

66 Laurie Fransman, British Nationality Law (London: Fourmat, 1989), 204.

67 (3080), 1984 (unreported); Pearl, Family Law, 44.

68 Ibid, 44-5; Fransman, British Nationality, 204. There appears to be a parallel between this line of cases and the early liberal approach of the Immigration Appeal Tribunal to appeals against the application of the primary purpose rule, which later became significantly tighter, see Sachdeva, The Primary Purpose Rule. 
approach can be seen since Zahra. Rokeya and Rably Begum $v$ Entry Clearance Officer, Dacca ${ }^{69}$ was another Bangladeshi case of a second wife and daughter of the male sponsor who typically led an international commuter' life between Sylhet in Bangladesh and Britain, having first arrived in Britain in 1962. His first marriage took place in Bangladesh in 1969, he became a citizen of the UK and colonies in 1972, and he married the first applicant in 1975 and his daughter by her was born in 1980. It was decided by the ECO and on appeal by the adjudicator that because the sponsor was domiciled in England at the time of the second marriage, that marriage was void. The Tribunal took care to set out factors for and against the conclusion that the sponsor had acquired a domicile of choice in England and, unlike in Zahra, cited authorities underlining that the burden of proof on those alleging that the domicile of origin had changed was a heavy one and stating that 'in the typical immigration case of a family split between England and another country the difficulty of satisfying the criteria is considerably increased.' It held that the sponsor's domicile had not changed at the time of his second marriage and allowed the appeal. So here we have a case in which the basic parameters of the so-called 'traditional' or 'dual domicile' test were not challenged by the Tribunal but rather that it sympathetically found a way to hold that the marriage was valid by adopting the view that the loss of the domicile of origin had not been convincingly established.

In the second case, Entry Clearance Officer, Dhaka, v Ranu Begum and Others,${ }^{70}$ the 'traditional' test was itself challenged by the Tribunal. This case also involved a Bangladeshi sponsor's second wife and their children. It was found here that the sponsor had initially married an English woman with whom he had four children but that since about 1953 he had not seen her, although he never went through divorce proceedings to end that marriage. $\mathrm{He}$ married the first applicant in 1969 in (what was then) East Pakistan. By the Tribunal stage the sole question was about the validity of the second marriage, although at earlier stages it seemed the main issue had been whether the applicants were related as claimed, a frequent inquiry in Bangladesh cases. The question of the sponsor's domicile therefore became a key point in the appeal. It was actually concluded by the Tribunal that although he had acquired a domicile of choice in England at the time of his first marriage, he had subsequently re-acquired his Pakistani domicile by 1969 , so that his second marriage too was valid under the 'dual domicile' or 'pre-nuptial domicile' test.

The Tribunal did not stop there, however. Since the second marriage in this case predated the dateline of 1 August 1971 given by the MCA, the Tribunal saw no reason to be restricted by section 11(d). Instead, it drew on the recent decision of the Court of Appeal in the matrimonial case of Lawrence $v$ Lawrence ${ }^{71}$ in which either the 'pre-marital domicile' or the 'intended matrimonial domicile' tests (this latter also expressed as the 'intended matrimonial
69 [1983] Imm AR 163.
70 [1986] Imm AR 461.
${ }^{71}[1985] 2$ All ER 733. 
residence' test or the law with which the marriage has a real and substantial connection) were thought to be useful as a way of recognising the marriage at issue. The relevant dicta in Lawrence had found support in one Tribunal decision already, ${ }^{72}$ although as in that case the Tribunal in Ranu Begum also found that it was difficult to establish the intention of the sponsor after the marriage with certainty, as he had intended to return to the UK for work each time after having visited Pakistan/Bangladesh. However, the Tribunal went on to find that:

In so far as the dicta in Lawrence $v$ Lawrence opened the gate to consideration of the law which has the most substantial connection with the marriage, we have no doubt that this was the law of Pakistan. All the factors point to Pakistan being the country most connected with the marriage. Even if we had not been able to find that the sponsor had lost his domicile . . . we would still have concluded that the law that has the most substantial connection with the marriage was that of Pakistan. We realise that Lawrence $v$ Lawrence was not concerned with the validity of polygamous marriages in English law and was concerned with a case where the intended domicile was English. However, as in Rafika Bibi we are thankfully relieved from the task of deciding whether, had the sponsor's domicile been English, the marriage should still be considered valid as the law with which the marriage had the most real and substantial connection was Pakistan.

The marriage was held to be valid according to English law as the findings on the two tests coincided, although as reflected in this statement, the Tribunal was certainly aware that it had narrowly escaped the burden of ratifying the idea that an English domiciliary was capable of contracting a polygamous marriage in an overseas jurisdiction (albeit only for marriages celebrated prior to 1 August 1971).

The impression that the law, as far the older marriages were concerned at any rate, was slowly moving to considering the overseas law is reinforced by some remarks made by Webster $\mathbf{J}$ in the unsuccessful application for judicial review in $R v$ Immigration Appeal Tribunal, ex parte Rafika Bibi. ${ }^{73}$ In that case, although the Tribunal had been impressed by the remarks favouring the 'real and substantial connection' test in the Lawrence judgment, they could not decide whether the sponsor's second marriage actually had a real and substantial connection in Bangladesh or that he had retained his domicile there. They therefore upheld the finding that the second marriage was void, while allowing the appeals of four children of this union. The second wife then somehow arrived at Heathrow some months later claiming entry. When this was refused a judicial review application challenging both the Tribunal decision and the immigration officer's refusal was made. Webster $\mathrm{J}$ was not persuaded that the Tribunal's approach had been unreasonable or perverse. He also refused to entertain the argument that the Tribunal ought to have made a decision that

72 Rafika Bibi (4603) (unreported); see Mole, Immigration, 42-3.

73 [1989] Imm AR 1. 
Bangladesh law was the most appropriate as the 'marriage was a Muslim marriage, celebrated in a Muslim community in Bangladesh; that at its date both the sponsor's wives were resident in Bangladesh, and that the only land or property owned by the sponsor was in Bangladesh'. However, in the course of the judgment, Webster $\mathrm{J}$ made the following observation:

Whatever the doubts or dispute there may be as to which of the two rival tests should be applied, I will assume that the real and substantial connection test should be applied if it results in upholding the validity of the marriage which would be invalid tested against dual prenuptial domicile.

This observation also seemed to favour the application of alternative tests, as had the Tribunal, with the aim of upholding the marriage if possible. ${ }^{74}$

At the very least, therefore, these newer cases indicate a more relaxed approach. Rokeya and Rably Begum shows that the Tribunal was willing to find that the domicile of origin had been retained to uphold a second marriage, and in Ranu Begum, that it had actually been recovered, with the same result. It is possible that the implications of the finding in Ranu Веgum, ie that the 'dual domicile' test was likely to no longer be used as the sole means of judging the validity of earlier polygamous marriages, may have also worried law makers. That this approach gained the support of the High Court could have caused such worries to grow. However, by the time the High Court gave its decision in Rafika Bibi on 11 February 1988, the wheels of legislation were already moving to introduce a statutory 'ban' on the entry of second wives, pushing domicile and choice of law questions firmly to the background. ${ }^{75}$

\section{THE BAN ON SECOND WIVES: THE INTERVENTION OF STATUTORY CONTROL}

By the late 1980s UK immigration law was already heavily involved in controlling the settlement of South Asians by legitimating the denial of entry to family members, ${ }^{76}$ while the fully fledged 'primary purpose rule', which served to effectively exclude a huge number of men married to South Asian

\footnotetext{
74 The approach was followed in Sofura Bibi (8601), 24 Feb 1992 (unreported), in another case involving a marriage entered into prior to 1 Aug 1971.

75 Another reason for refusal continued to cause problems, however. This was the contradiction that was often apparent in sponsors declaring that they saw the UK as their future home for the purpose of supporting their spouse's settlement application, and the same information then being used by ECOs to argue that the sponsor's domicile of origin had therefore been lost, leading to a declaration of invalidity of the marital relationship. Refusals based on this line of reasoning were, however, successfully challenged before the Tribunal in Rukshana Begum Chowdhury (9965), 20 Jan 1993, and before Sedley J in $R v$ Immigration Appeal Tribunal, ex parte Miah (CO/2100/92), 14 June 1994 (both unreported). See, further, David Jackson, Immigration: Law and Practice, 2nd edn (London: Sweet \& Maxwell, 1999), 58 and Macdonald and Webber, Immigration Law and Practice, 423-4.

76 Juss, Discretion.
} 
women resident in the UK, was also in full operation by this time. ${ }^{77}$ Through the Immigration Act of 1988 and accompanying Immigration Rules, UK law then effectively imposed an outright ban on the admission of a wife where another wife had already been admitted. This legislation marked a new departure in the attempt within British law to control polygamy through immigration restrictions. In the following sections we therefore examine the background to and details of the legislation, and also analyse the reaction of the courts in cases challenging decisions made subsequent to this legislation.

\section{A. The Immigration Act 1988 and Accompanying Restrictions}

The sequence of events leading to the passage of the 1988 Act, as well as the other, non-polygamy provisions in it, are also of interest in this context. Many South Asian men, Bangladeshis (formerly East Pakistanis) being the most important group here, who came to work in the UK in the earlier periods of post-war migration acquired a right of abode under the 'partiality' provisions of the Immigration Act 1971. While South Asian men could not generally establish such a right through ancestral connections or birth in the UK, many were able to do so after five years residence in the UK, or by registering in the UK as citizens of the UK and colonies, as Gardner and Shukur indicate (see III.B., above). Importantly, under the patriality provisions such men could also pass a right of abode on to their wives, including second wives, and therefore an unfettered right to enter the UK. There was a proviso under section 3(9) of the Immigration Act 1971 that would have applied to most such wives; namely that they should obtain a 'certificate of entitlement to partiality' (later 'right of abode') before travelling to the UK. Furthermore, under the 1971 Act children of patrial men who had registered as CUKCs themselves acquired a right of abode and upon the coming-into-force of the British Nationality Act 1981, these children were entitled to claim the status of British citizens. They could therefore travel to the UK without the need for certificates of entitlement, even on Bangladesh passports, and without being subject to immigration control. ${ }^{78}$

The key events which then led to the 1988 Act being passed very much lead the observer to conclude that the main target of control were family members from Bangladesh, a group which appears to have suffered much of the worst forms of immigration control, partly because of the relatively delayed trend to reunite families as compared with other South Asians (see III.B. above). As Fransman recounts:

The Bangladesh British citizens by descent began to arrive in 1985 and during 1986 the numbers increased substantially. However, as of 16 October 1986, the

77 Sachdeva, The Primary Purpose Rule.

78 See, in detail, Fransman, 'Family Settlement Cases: a Denial of Statutory Rights' (1986) 1(1) Immigration and Nationality Law and Practice 5-15; Fransman, British Nationality, 210-31. 
UK government made Bangladeshis visa nationals. As a matter of law, those claiming British citizenship by descent did not require visas but the airlines, fearful of financial penalties, simply refused to carry any Bangladesh passport holder without a visa. The result was that in all but a few isolated cases the flow of claimants from Bangladesh was halted.

The government however, was not satisfied with a mere de facto prevention of direct arrivals of claimants of British citizenship by descent. The introduction of visas may have placed a hurdle in the path of claimants wishing to travel direct to the UK, but did not affect their legal right to do so. Accordingly, after the 1987 election the government announced its intention to amend the law and so to extinguish the statutory entitlement. ${ }^{79}$

Thus, section 3(1) of the Immigration Act 1988 replaced sections 3(9) and 3(9A) of the 1971 Act with a new section 3(9) that imposes a requirement on all claimants to the right of abode or British citizenship when seeking to enter the UK, to establish that status by obtaining a certificate of entitlement or a British passport. This provision obviated the risk of claimants to entry by simply arriving at a British port, and rather attempted to ensure that controls were applied at diplomatic posts abroad where any adverse publicity could be avoided.

Not content with this draconian interference with rights of abode already in existence, the 1988 Act also removed, by its section 1, the protection contained in section 1(5) of the 1971 Act that wives and children of those Commonwealth citizens who were already settled by 1 January 1973 would not be subject to requirements any more onerous than those in existence on that date. Section 1(5) was 'originally enacted to give confidence to Commonwealth citizens settled here that increasingly restrictive immigration policies were not aimed at driving them away or preventing their families joining them in the UK' ${ }^{80}$ Judging by the anthropological accounts discussed above (III.B.), it does not appear that this section alone was able to inspire such confidence as other restrictions soon came to bear upon these migrants that spurred them on to hasten the process of family reunion. However, as a consequence of the change, this group of men and their families have also been subject to the significantly harsher requirements for family reunion that have been imposed since 1973 such as the 'primary purpose rule' and 'maintenance and accommodation' requirements. ${ }^{81}$ The change has also meant that further restrictions can be applied simply by way of changes to the

79 Fransman, British Nationality, 215

80 Sachdeva, The Primary Purpose Rule, 40.

81 The requirement to maintain and accommodate immigrating family members were introduced by changes in the Immigration Rules, HC 503 (1985): see Sachdeva, The Primary Purpose Rule, 91-100. They became crucial in practice after the 1988 Act. On this and more generally on the impact of the 1988 Act, see Prakash A Shah, 'Bangladeshis in English Law' (Paper Presented at Conference on 'Bangladeshis in Britain: Changes and Choices, Configurations and Perspectives', 24 and 25 May 2002, London Guildhall University, also at <http://www.casas.org.uk>). 
Immigration Rules, which are subject to alteration by the executive. As a result, the changes to the Rules concerning polygamously married couples also affect them.

The key provision of the 1988 Act applying to polygamously married wives is found in section 2, although that only relates to their exercising a right of abode or obtaining a certificate of entitlement. Accompanying changes to the Immigration Rules extended the reach of the prohibition to preclude such wives obtaining entry clearance, leave to enter or variation of leave to remain. ${ }^{82}$

Section 2 of the 1988 Act applies to a wife, A, who acquired a right of abode by virtue of a marriage to a man who also had a right of abode as provided for in the Immigration Act 1971. Such a wife is prevented from exercising her right of abode, or from acquiring a certificate of entitlement if there is another woman, B, living who is the wife or widow of the husband and who is or has, since her marriage to the husband, been in the UK or has been granted either a certificate of entitlement or an entry clearance. The Act does not therefore envisage $\mathrm{A}$ as exercising a right of abode acquired as a result of the 1971 Act's patriality provisions if B has previously been or remains in the UK, regardless of whether the husband remains alive. A may only exercise this right where $\mathrm{B}$ has been in the UK as a visitor, an illegal entrant or has been granted temporary admission. An exception is also provided if A was present in the UK before 1 August 1988 or if A had been in the UK at any time since her marriage before $\mathrm{B}$ became a wife.

The changes prevent wife A from obtaining entry clearance, leave to enter or remain or a variation of leave to remain as a wife of a man who is married to $\mathrm{B}$, if $\mathrm{B}$ is or has at any time since her marriage to the husband been in the UK or if she has been granted a certificate of entitlement. Similar exceptions apply in this case, so that entry clearance, leave to enter or variation of leave may still be granted if A has been in the UK before 1 August 1988 having already come for settlement as the wife of the husband or if she has, since her marriage to the husband, been in the UK at any time when there was no wife B. Apart from that, A may again only obtain entry clearance, leave to enter or variation of leave if B has been in the UK as a visitor, an illegal entrant or has been granted temporary admission. The Rules do not, however, envisage a total ban and wife A could theoretically obtain entry as a visitor, as the prohibition applies to entry or stay as a wife only. It is to be noted that both under the Act and the Rules B and A may not be first and second wives respectively, but rather it is the presence of either wife in the UK which precludes the other

\footnotetext{
82 These came into force on 1 Aug 1988 as amendments to the then prevailing statement HC 169, paras 1B-1D; see Peter RH Moss, 'Statement of Changes in the Immigration Rules HC 555: a Note for Practitioners' (1988) 3(3) Immigration and Nationality Law and Practice 54-6. The same were later to be incorporated in HC 251 (1990), paras 3-5 and are currently to be found in HC 394 (1994), paras 278-80 with some amendment.
} 
from enjoying her right of abode or obtaining entry clearance, leave to enter or variation of leave.

Unlike the other changes introduced by the 1988 Act, the polygamy provisions were certainly not seen by legislators as making a great impact on the presence of South Asians in the UK in terms of their numbers. Home Secretary, Douglas Hurd, speaking of what became section 2, stated:

I do not wish to exaggerate the point. The number of polygamous wives coming here is quite small: we estimate that perhaps 25 or so polygamous households are set up here every year. However, polygamy is not an acceptable social custom in this country. I have no doubt that it would cause serious damage to community relations if it became generally understood that men settled here could continue to bring in a number of wives each. I very much hope that, on reflection, the Opposition will not make an issue of the change. The numbers involved are quite small, but the principle is not acceptable. The sooner we make that clear in the law of the land, the less likely it will be that damage to community relations will result. ${ }^{83}$

Responding to the provisions of the Bill, Roy Hattersely MP stated that the Bill was 'less concerned with legislation than with propaganda' ${ }^{94}$ and others saw the measure as more politically motivated than about the numbers involved. ${ }^{85}$ Still others saw it as justifiable given its gender equality undertones. For example, Anne Widdecombe MP observed:

We have heard about the 25 cases of polygamy—not a great deal many ... But, speaking as a woman, I find polygamy and arranged marriages wholly at odds with what the European Court of Human Rights has said about the equality of women. ${ }^{86}$

Thus, it seems that unlike some other parts of the immigration control agenda at this time, this was hardly an issue directly relevant to the 'numbers game' as it had come to be known. Rather, it appears to be more to do with the continuance of 'alien' customs and cultures regarded as unacceptable in Britain. As we have seen, there is a long history of uneasiness about polygamy in Britain and although the initial defences against it were built upon the doctrinal presuppositions of Christianity, these have now metamorphosed into the unacceptability of the custom on grounds of 'community relations' or the norms of gender equality and human rights. ${ }^{87}$ Of course, it may also be argued that by focusing on the pluralisation of cultural norms in Britain, wider immigration control agendas could be pursued or justified, as indeed seems to be true of the 1988 Act.

83 HC Debs, vol 122, col 785.

84 Ibid, col 189.

85 Stuart Randall MP, HC Debs, vol 122, col 846

86 Ibid, col 826.

87 See Poulter, 'The Claim to a Separate Islamic System'; Sebastian Poulter, 'Multiculturalism and Human Rights for Muslim Families in English Law', Michael King (ed), God's Law Versus State Law. The Construction of an Islamic Identity in Western Europe (London: Grey Seal, 1995), 81-7; Hamilton, Family, 71-3. 


\section{B. The One-wife Policy in the Courts}

The 1988 legislation meant that for actually polygamous couples, the prospect of securing full family reunion rights was now overridden by statute, although as seen earlier (at III.C.), the position under private international law had still allowed some room for manoeuvre at the official legal levels. This does not, however, mean that validity of marriages is not a concern of the immigration authorities, as we are still told that 'polygamy is the issue of validity most commonly faced in the context of immigration. ${ }^{, 88}$ On the other hand, the case law that came after the 1988 legislation is much less concerned with the validity of marriages under private international law than was the case before then, and instead rather tends to be focused on the limits of the exercise of administrative discretion that now governs the admission of polygamously married wives.

A valiant attempt to declare the Immigration Rules on polygamously married wives ultra vires by means of a judicial review challenge in $R v$ Immigration Appeal Tribunal, ex parte Hasna Begum did not succeed. ${ }^{89}$ The case actually involved a long-standing second wife in Bangladesh who had never had accommodation of her own and from the High Court's judgment it looks as if her mother and brother had no longer wanted to maintain her, nor to allow her to remain in the same house as them, the brother's wife and their seven children. In the Court of Appeal the circumstances were made slightly clearer in that the brother's evidence indicated that his sister ought to live with her husband, with whom she had never lived, a situation that was of some concern to her mother. It is this background that appears to have motivated the application in the first place although this is hardly discussed in the judgments. Effectively, here was a challenge to the Rules that sought to get the UK courts to enforce the duties of a husband consistently with South Asian norms. On this reading the husband was relying on the official legal position to evade his responsibilities. However, at the High Court, Tucker J, while sympathetic, did not find the Rules to be ultra vires. Neither did Aldous LJ, who gave the leading speech for the Court of Appeal, accept the argument that while the Immigration Act 1971 allowed the making of Immigration Rules which imposed restrictions on the entry of spouses, it did not allow an outright prohibition on the entry of either monogamously or polygamously married spouses.

Attempting to circumvent the official ban on second wives could lead to the jeopardisation of immigration status as found out by the applicant in $R v$ Secretary of State for the Home Department, ex parte Zeenat Bibi..$^{90}$ The case concerns a young second wife of a sponsor who had been in the UK since 1967; he registered as a 'British citizen' (probably rather as a 'citizen of the UK and colonies') in 1974, and returned to Pakistan to marry and return with

\footnotetext{
88 Jackson, Immigration, 57. Macdonald and Webber, Immigration Law and Practice, 418 discuss polygamous marriages as one of the areas, together with the recognition of talaq divorces, where there were 'particular problems likely to be encountered in immigration cases'.

89 [1995] Imm AR 249.

90 [1994] Imm AR 326, QBD.
} 
his wife in 1975. The couple appear to have been childless, as was revealed only at the Court of Appeal stage, ${ }^{91}$ and it may be that this was the reason (although we are not informed) that the couple returned to Pakistan in 1989 where the husband married the applicant. The applicant arrived in the UK in 1991, but as a visitor, having informed the authorities that she was already engaged to a man in Saudi Arabia. She later revealed that she had been informed by someone who was 'educated' that if she disclosed her true marital status, she would not have a chance of obtaining admission to the UK. After arrival she soon became pregnant and had two children by the time of the hearings. Upon her first pregnancy she applied for variation of leave as a spouse, once interviewed with her husband she was declared an illegal entrant, and later informed of the refusal of her application to remain in the UK.

Not much argument seems to have ensued regarding the validity of the marriage when the application for leave for judicial review was heard, nor when it was renewed in the Court of Appeal. The Secretary of State's letter described the second marriage as 'invalid and polygamous'. Pill J in the lower court assumed that the second marriage was not valid because the sponsor had an English domicile, while Russell LJ in the Court of Appeal, assuming validity, pointed out that the Immigration Rules would have frustrated any application as a spouse. Although the Home Secretary's refusal letter proposed to remove the applicant and her two children, neither court was moved to hold that removal was unreasonable in light of the fact that the children, as British citizens, had a right of abode in the UK. This is a particularly disappointing case with the judges blindly following the statutory rules without regard to the human factors involved, but also a logical consequence of the 1988 Act where a party to a marriage seeks at first not to disclose her true status, indicative as we shall see of a wider phenomenon of polygamy moving 'underground', rather than ceasing altogether. Women in this situation find themselves in an extremely weak legal position, subject to harassment and removal by state officials who are free to make hurtful allegations implying zina (illicit or unlawful sexual intercourse), and potentially by the other parties to the marriage, although that does not appear to have been the situation in this case.

Another reported immigration case, $R v$ Secretary of State for the Home Department, ex parte Laily Begum ${ }^{92}$, involved a widow from Bangladesh who bore four children before her husband died. She was his second wife. She was refused a certificate of entitlement in 1992 as a direct consequence of the 1988 Act, although her four children were issued with British passports. She then sent them to the UK where they were sent into local authority care. Some two and a half years later she managed to arrive in the UK and claimed asylum when she was refused leave to enter with false American visas. She was allowed to live with her children who were in foster care, although she was

\footnotetext{
91 Zeenat Bibi v Secretary of State for the Home Department [1994] Imm AR 550.

92 [1996] Imm AR 582.
} 
refused exceptional leave to remain on the basis that she and the children could continue life in Bangladesh. One of her sons was 18 at the time of the hearing, although she had with her two daughters aged 14 and 16 and another son aged 12. Two of the four children were said to have suffered from severe emotional problems. Among the arguments raised in the application for leave to apply for judicial review was that the Secretary of State had not treated as paramount the interests of the children, as would be required under the Children's Act 1989. Dyson J felt, however, that the Secretary of State was not bound by the Children's Act and that what weight he placed on the children's interests was for him to decide. This case reinforces the impression that even where children have British citizenship, UK immigration law regards their mother as removable or deportable from the UK. Nobody seems to have thought it relevant to argue that the mother in this case was initially separated from her children because of the retroactive removal of her right of abode. This case also highlights the different standards of child protection thought appropriate between the family court jurisdiction and the immigration context.

Much of the case law that emerged subsequent to the 1988 legislation involved not only polygamously married wives but also their children in the background. It therefore must have looked very obvious that UK law was actively engaged in separating families by granting entry to children of mothers who themselves were being refused. In the 1994 restatement of the Immigration Rules a new paragraph was inserted that allowed (even mandated) refusal to children whose mothers would be liable to be refused for being polygamously married ${ }^{93}$ Menski recalls how this provision was inserted despite arguments against it, partly based on human rights grounds, by representative organisations, finding it to be a reflection of the "entirely negative approach to polygamous marriages and children from such marriages' ${ }^{94}$ Whether this provision was inserted in response to the increasing visibility of child-related case law is uncertain, but it would certainly have allowed refusals to be issued in a low-key manner against some children, particularly those who were too young to benefit from the citizenship provisions discussed above (IV.A.).

The position of children of polygamous marriages, previously thought to be entitled to British citizenship, is also now under question by the recent judgment of the Court of Appeal in Azad v ECO, Dhaka. ${ }^{95}$ Whereas the conventional wisdom had hitherto been that the Legitimacy Act 1976 operates to allow children to acquire citizen status through the father, even where a marriage may not be considered valid as under English law ${ }^{96}$, this position now seems to have changed through judicial fiat. The Legitimacy Act merely requires a reasonable belief in one or both of the parties to the marriage as to its validity. Jacob J giving the only reasoned speech for the Court held,

93 HC 395 (1994), para 296.

94 Menski, 'Family Migration and the New Immigration Rules' (1994) 8(4) Immigration and Nationality Law and Practice 112-24, at 118 .

95 [2001] INLR 109 [2001] Imm AR 318.

96 Pearl, Family Law, 48. 
however, that such reasonable belief must be related to validity under English law, notwithstanding the fact that the marriage in question had taken place in Bangladesh and that the marriage was considered lawful under Bangladeshi law. As the present writer has argued elsewhere, this case represents an extremely worrying step by the judiciary, which seems to be participating in the building of a highly negative private international law position led primarily by immigration control concerns. ${ }^{97}$

As we saw earlier (IV.A.) restrictions on polygamy have been increasingly founded on human rights grounds. However, the fact that UK law restricts the immigration of spouses who regard themselves as legitimately married and therefore entitled to reside together in the same country could itself just as well be argued to be a violation of human rights. In the so far unpublished decision of Bibi v UK ${ }^{98}$ the European Commission found such a restriction to be consistent with the provisions of the European Convention on Human Rights. As Karen Reid tells us:

The Commission found that excluding surplus wives was a legitimate aim under the second paragraph of Article 8 for the preservation of a Christian-based monogamous culture dominant in that society (as pursuing the protection of morals and of rights and freedoms of others). It also recalled its findings in an unpublished Dutch case that a Contracting State cannot be required to give full recognition to polygamous marriages in conflict with their own legal order, referring to bigamy laws. ${ }^{99}$

It therefore appears that the UK government may have attempted to justify in Strasbourg restrictions on polygamy on the basis of the dominance of monogamy as underpinned by Christian norms. We do not, however, have information about what was meant by the 'protection of morals and of rights and freedoms of others' in this context. It nevertheless seems, on the basis of the above case law, that the European human rights fora may not be prepared to countenance complaints against restrictions on polygamously married spouses, whether in immigration or in any other field. ${ }^{100}$

\section{POLYGAMY AS ILLUSTRATIVE OF THE PROBLEM OF ETHNIC MINORITY LAWS}

It is apparent that particularly since the 1988 legislation, UK law takes a particularly hard line against the admission of polygamously married wives,

\footnotetext{
97 Prakash Shah, 'Children of Polygamous Marriage: an Inappropriate Response' (2002) 16(2) Immigration, Asylum and Nationality Law 110-13.

98 Appl. 19628/92, Bibi v UK (Dec) 29 June 1992.

99 Karen Reid, A Practitioners' Guide to the European Convention of Human Rights (London: Sweet \& Maxwell, 1998), 277.

100 This case law of the Commission obviously assumes importance at the domestic level given the Human Rights Act 1998. One may speculate on this basis what the European Court of Justice may make of an application to include a polygamously married wife as a 'spouse' for the purposes of European Community law, for example, under Reg 1612/68 on the free movement of workers.
} 
although under the 'domestic' matrimonial law recognition was already refused, together with the possibility of criminal prosecution. It is also notable that legislation against polygamy in this way, if not necessarily directed at Muslims, has been closely associated with controlling the immigration of South Asian Muslims, as the case law also appears to indicate. The statutory ban on second wives coincided with the high point of political agitation against the Muslim presence in Britain in education and was very soon overshadowed by the Satanic Verses affair. ${ }^{101}$

However, it can be questioned whether the purported ban on polygamy either by prohibiting the contraction of more than one marriage in Britain or by preventing the admission of second wives achieves its actual abolition, assuming of course that this is itself desirable in all situations. There is now considerable evidence to the effect that Muslims living in Britain have generally been able to adapt shari'a to the British scene by taking cognisance of multiple legal levels according to what Menski has termed 'angrezi shariat'British-Muslim law. ${ }^{102}$ On the other hand, some Muslims have consciously preferred to keep, or have had to keep, certain legal acts 'within the community' so to speak, a situation in which the official legal position colludes by the pretence that only English law (or Scottish law) ${ }^{103}$ is being followed. ${ }^{104}$ How far this is the case for other ethnic minorities remains under-explored, although Menski has already diagnosed a similar tendency among South Asians more generally. ${ }^{105}$ Certainly, the evidence in reported case law

101 Philip Lewis, Islamic Britain. Religion, Politics and Identity among British Muslims (London: IB Tauris, 1994), 2-7, in his Bradford-focused study, highlights education and the burning of the Satanic Verses as the two most prominent features publicly connected with Muslims in the Britain of the 1980s. Both issues had their legal impacts in different ways. The Education Reform Act of 1988 sought to reinforce the notion that worship and religious education in English schools ought to reflect Christian traditions: see A Bradney, 'The Dewsbury Affair and the Education Reform Act 1988' (1989) 1(2) Education and the law 51-7. The Satanic Verses affair meanwhile led to a debate on the scope of English blasphemy law: see Jones and Welhengama, Ethnic Minorities, 179-212.

102 Pearl and Menski, Muslim Family Law, 74-7.

103 It appears that the long-standing ambiguity about the position of persons deemed to have acquired Scottish domicile prior to a second marriage has been resolved by the Immigration Appeal Tribunal in favour of following the English approach, that is, to treat the second marriage as void-see Abida Naseem (11415), 12 Oct 1994 (unreported). The case is arguably superseded now by the Private International Law (Miscellaneous Provisions) Act 1995, section 7, to similar effect however (see text at III.A.).

104 Pearl and Menski, Muslim Family Law, 77-80; Yilmaz, Dynamic Legal Pluralism. The growing literature about alternative dispute resolution offered by shari'a councils of various types in Britain testifies to the widening chasm between Muslims and the official legal system. See Zaki Badawi, 'Muslim Justice in a Secular State', Michael King (ed), God's Law Versus State Law. The Construction of an Islamic Identity in Western Europe (London: Grey Seal, 1995), 73-80; Lucy Carroll, 'Muslim Women and 'Islamic Divorce' in England' (1997) 17(1) Journal of Muslim Minority Affairs 97-115; Pearl and Menski, Muslim Family Law, 77-80, 393-8; Sonia Nûrîn Shah-Kazemi, Untying the Knot. Muslim Women, Divorce and the Shariah (London: Nuffield Foundation, 2001).

105 Menski, 'Asian Laws in Britain and the Question of Adaptation to a New Legal Order: Asian Laws in Britain?', Milton Israel and NK Wagle (eds), Ethnicity, Identity, Migration: the South Asian Context (Toronto: Centre for South Asian Studies, University of Toronto, 1993), 238-68, at 255 . 
concerning polygamy, particularly in the non-immigration sphere, is hardly restricted to Muslims.

At any rate, for Muslims in Britain, Yilmaz presents specific evidence about the practice of polygamy in that one marriage is contracted under shar$i^{\prime} a$ while another marriage may take place under both the official law as well as shari'a. The same result may be achieved by declaring only one marriage for immigration purposes while another marriage may well take place in the UK under shari'a only, although the image that the marriage is a monogamous one is retained officially. ${ }^{106}$ The polygamy example shows therefore that ethnic minorities have not remained passive recipients of official dictates. Rather, there is evidence of their reliance on their own cultural resources to secure acceptable outcomes for themselves, and they are often able to negotiate between different legal levels in order to do so, thereby calling into question the claims about the dominance of the official legal system.

On the other hand, the evidence cited shows, consistently with that in other jurisdictions, that official bans on social practices such as polygamy are illadvised and drive the phenomenon underground. The risk of abuse here is great, as is the potential vulnerability of women and children who may simply be abandoned without a divorce recognised under the personal law of the parties and without recourse to official legal fora for remedy. If anything, the official law exacerbates the weaker legal position of women and children, often dividing families across continents by disrespecting their choices, as seen particularly in the operation of the post-1988 immigration regime. In the case of Bibiv Chief Adjudication Officer, the Court of Appeal upheld a refusal to allow a widow of a polygamously married husband to claim a widowed mother's allowance. ${ }^{107}$ This case again highlights, in a non-immigration scenario, the wide gap in protection for wives under the official law, and shows that when polygamy issues do come up for resolution in official fora the courts are unable to offer relevant solutions.

A similar situation can be seen in the recent case of $A-M v A-M,{ }^{108}$ involving a polygamously married Arab couple. It seems that official legal recognition was only thought to be necessary after legal advice, rightly, indicated that the Muslim nikah performed in London would not confer validity and that other legal problems were therefore likely to arise. Recognition was then sought to be secured by 'forum shopping' in different Arab states. Predictably, the case is overly-focused on recognition issues, with Hughes J underlining the importance of following English law rules on solemnisation. One wonders

106 Yilmaz, Dynamic Legal Pluralism, 167. Ihsan Yilmaz, 'The Challenge of Post-Modern Legality and Muslim Legal Pluralism in England' (2002) 28(2) Journal of Ethnic and Migration Studies 343-54, at 348-9.

107 [1998] 1 FLR 375, [1998] 1 FCR 301, [1997] Fam Law 793. Other similar cases are $R v$ Department of Health, ex parte Misra [1996] 1 FLR 128, QBD concerning entitlement to a pension scheme and widow's benefit where there were two Hindu widows, and Al Mansorri v Social Security Commissioners, 12 July 1995, CA (unreported), concerning widow's benefit where the second wife was also deceased. 
how long English law will be able to continue turning a blind eye to ethnic minority legal facts in this way by insisting on the (sometimes impossible) expectation of compliance with formal requirements, as complex issues will inevitably now often arise especially in disputes over property rights. ${ }^{109}$

In light of the clearly unsatisfactory official position in the area of polygamy, it may legitimately be asked how the law should develop from here. The issues clearly go beyond the immigration sphere where there is an obvious problem for the reunification of families divided between continents. The solution in the immigration scenario would be to remove the unjustifiable obstacles imposed by the Immigration Act 1988 and under the Immigration Rules. However, there would still remain the defensive English law position against recognising polygamous marriages for any other purposes. An apparent solution here might lie in reforming English private international law so that marriages contracted validly according to the law in a jurisdiction abroad might be given effect for all relevant purposes in the UK. Nevertheless, even such a reform would fail to capture the full extent of the problems arising in this area. The long-term establishment of Afro-Asian ethnic minorities, and therefore the establishment of Afro-Asian legal cultures in Europe, leads to questions as to whether private international law offers a realistic prism through which the legal status of such people can be assessed. ${ }^{110}$ Private international law is too encumbered by notions such as domicile (or nationality or residence) that try to fix parties to a territorially determined jurisdictional law. It is even argued that this way of treating people entrenches their 'foreignness' through legal structures. ${ }^{111}$ On the other hand, it is far from being the case that Western legal systems are prepared to move towards the Afro-Asian model of personal laws. Nevertheless, it cannot be ignored that the UK and other Western societies are pluralising in unprecedented ways and legal systems will have to remain responsive to such developments. Assimilationist strategies, as seen in this case study of polygamy under English law, lead to such phenomena going underground or result in vulnerable persons, generally women and children, being doubly disenfranchised by official law. It therefore remains essential for a justice-focused legal system to remain sensitive to the context and ethnicity of the persons that come before it. ${ }^{112}$ In that case, phenomena such as plural marriage ought to be accepted as constituting one form of family arrangement within a plural society that may give rise to problems which require resolution by official fora.

\footnotetext{
109 Gandhi v Patel [2002] FLR 603 is a recent Hindu case where an inheritance dispute leads a widow to resort to court, for her only to discover that her polygamous Hindu marriage contracted in England was a 'non-marriage', as distinct from a 'void' marriage, thus altogether disentitling her from challenging the will of her deceased husband.

110 Foblets, 'Conflicts of Law'; Ferrari, 'Introduction'. 111 Ibid

112 For suggestions centring on the need for state responsiveness to cultural pluralism, see Menski, 'Asian Laws' and Ihsan Yilmaz, 'Law as Chameleon: The Question of Incorporation of Muslim Personal Law into the English Law' (2001) 21(2) Journal of Muslim Minority Affairs 297-308.
} 


\section{GLOSSARY}

Translations are given according to meanings used in this article:

\begin{tabular}{|c|c|}
\hline angrezi & English/British \\
\hline desh pardesh & a home abroad \\
\hline firman & command, edict \\
\hline imam & leader of the ritual prayers \\
\hline nikah & Muslim marriage \\
\hline shari'a & the divine law of Islam \\
\hline alaq & unilateral divorce issued by a man \\
\hline na & illicit or unlawful sexual relationship \\
\hline
\end{tabular}

